\title{
Bioedusiana
}

\section{PERBEDAAN HASIL BELAJAR SISWA PADA MATERI SISTEM PENCERNAAN PADA MANUSIA DENGAN MENGGUNAKAN MEDIA POWER POINT DAN MEDIA TORSO}

\author{
The Difference Of Student Learning Outcomes In The Study Of Human Body Anatomy In Human \\ Digestion System Using Power Point And Media Torso Media
}

\author{
${ }^{1}$ Popo Musthofa Kamil
}

1) Jurusan Pendidikan Biologi FKIP Universitas Siliwangi, Jalan Siliwangi Nomor 24, Tasikmalaya - 46115 Email korespondensi: popo.febrian1602.@gmail.com

\begin{tabular}{l}
\hline Info Artikel \\
\hline Keywords: \\
Media power point, torso, \\
study results \\
\hline
\end{tabular}

\begin{abstract}
Abstrak
Penelitian ini bertujuan untuk mengetahui perbedaan hasil belajar siswa yang proses pembelajaranya menggunakan media pembelajaran powerpoint dengan media Torso pada Materi Sistem Pencernaan pada Manusia di kelas XI IA SMAN 5 Tasikmalaya. Penelitian ini dilaksanakan mulai Januari $2015 \mathrm{~s} / \mathrm{d}$ Mei 2016 di kelas XI IA SMA N 5 Tasikmalaya. Metode yang digunakan adalah metode quasi eksperiment. Populasi penelitian adalah seluruh kelas XI IA SMAN 5 Tasikmalaya tahun ajaran 2015/2016 sebanyak 3 kelas dan sampel yang digunakan sebanyak 2 kelas yaitu kelas XI IA 2 dan XI IA 3 yang diambil dengan cara cluster random sampling. Teknik pengumpulan data pada penelitian ini adalah dengan menggunakan teknik tes. Data yang diperoleh dari hasil tes akhir dianalisis dengan menggunakan uji t. Hasil analisis menunjukan terdapat perbedaan hasil belajar siswa yang proses pembelajarannya menggunakan media powerpoint dengan media Torso pada Materi Sistem Pencernaan pada Manusia di kelas XI IA SMAN 5 Tasikmalaya. Siswa yang proses pembelajarannya menggunakan media powerpoint diperoleh rata-rata 18,4, lebih baik jika dibandingkan dengan siswa yang proses pembelajarannya menggunakan media Torso yang memperoleh rata-rata 16,2.
\end{abstract}

\section{Abstract}

This study attempts to know the difference of the results student learning which the processes of learning uses the learning media powerpoint by the torso to the matter digestive system on human beings in class XI sman 5 tasikmalaya. Research be held on january 2015 until may 2016 in class XI high school 5 tasikmalaya. Methods used is the method quasi eksperiment. Population research is the entire class XI sman 5 tasikamalaya academic year 2015 / 2016 about three classes and sample used as much as two classes class XI 2 and XI 3 taken by means of clusters random sampling. Technique data collection in this research is by using technique test. The data collected from test results the end of were analyzed using test $t$. the results of the analysis showed there are the difference of the results student learning which the processes of pembelajarannya uses the media powerpoint by the torso to the matter digestive system on human beings in class XI sman 5 tasikmalaya. Students who processes pembelajarannya uses the media powerpoint obtained the average 18 ,

(C) 2018 Universitas Siliwangi

\footnotetext{
Alamat korespondensi:

Jurusan Pendidikan Biologi FKIP Universitas Siliwangi

Gedung Perkantoran FKIP Lt. 3

Jalan Siliwangi No. 24 Kota Tasikmalaya 46115

HP. 081235955555 (a.n. Romy Faisal Mustofa, M.Pd.)

E-mail: syahla.aini@gmail.com
}

ISSN 2477-5193 


\section{PENDAHULUAN}

Media pembelajaran adalah suatu alat yang berfungsi untuk menyampaikan pesan pembelajaran. Pembelajaran adalah sebuah proses komunikasi antara pembelajar, pengajar dan bahan ajar Media pembelajaran yang baik harus memenuhi beberapa syarat. Media pembelajaran harus meningkatkan motivasi pembelajaran. Penggunaan media mempunyai tujuan memberikan motivasi kepada pembelajar. Selain itu media juga harus merangsang pembelajar mengingat apa yang sudah dipelajari selain memberikan rangsangan belajar baru. Media yang baik juga akan mengaktifkan pembelajarn dalam memberikan tanggapan, umpan balik dan juga mendorong mahasiswa untuk melakukan praktek-praktek dengan benar.

Ada beberapa jenis media pembelajaran yang bisa digunakan dalam proses pengajaran sebagaimana dikemukakan oleh Sudjana, Nana dan Ahmad Rivai (2012: 3) yaitu :

1) media grapis (media dua dimensi), yaitu media mempunyai ukuran panjang dan lebar. Contohnya adalah gambar, foto, grafik, bagan atau diagram, poster, kartun, komik;

2) media tiga dimensi, yaitu dalam bentuk model seperti model padat (solid model), model penampang, model susun, model kerja, moek ups, diorama; dan

3) media proyeksi, seperti slide, film, stripe, film, penggunaan OHP.

Menurut Jelita (2010) microsoft Power Point adalah suatu software yang akan membantu dalam menyusun sebuah presentasi yang efektif, professional, dan juga mudah. Media powerpoint bisa membantu sebuah gagasan menjadi lebih menarik dan jelas tujuannya jika dipresentasikan karena media powerpoint akan membantu dalam pembuatan slide, outline presentasi, presentasi elektronika, menampilkan slide yang dinamis, termasuk clipart yang menarik, yang semuanya itu mudah ditampilkan di layar monitor komputer. Kelebihan dan Kekurangan Media Power Point Menurut Sanaky (2009), Microsoft powerpoint memiliki beberapa kelebihan dan kelemahan adalah sebagai berikut:

Kelebihan microsoft powerpoint antara lain:Keunggulan/ kelebihan power point yaitu salah satu fitur menyediakan kemampuan untuk membuat presentasi yang meliputi musik yang memainkan seluruh presentasi atau efek suara untuk slide tertentu. Selain kemampuan untuk menambahkan file suara, presentasi dapat dirancang untuk berjalan, seperti film, sendiri. PowerPoint memungkinkan pengguna untuk merekam slide show dengan narasi dan laser pointer. Pengguna dapat menyesuaikan tampilan slide untuk menampilkan slide dalam urutan yang berbeda dari awalnya dirancang dan memiliki slide muncul beberapa kali. Microsoft juga menawarkan kemampuan untuk menyiarkan presentasi untuk pengguna tertentu melalui link dan Windows Live. Dan kelebihan yang lain dari power pointa dalah sebagai berikut.

1) Praktis, dapat dipergunakan untuk semua ukuran kelas

2) Memberikan kemungkinan tatap muka dan mengamati respons siswa

3) Memiliki variasi teknik penyajian yang menarik dan tidak membosankan

4) Dapat menyajikan berbagai kombinasi clipart, picture, warna, animasi dan suara sehingga membuat siswa lebih tertarik

5) Dapat dipergunakan berulang-ulang Kelemahan diantaranya adalah 
1) Tidak semua materi dapat METODE disajikan dengan menggunakan powerpoint

2) Membutuhkan keterampilan khusus untuk menuangkan pesan atau ide-ide yang baik pada desain program komputer microsoft powerpoint sehingga mudah dicerna oleh penerima pesan

3) Memerlukan persiapan yang matang, bila menggunakan teknikteknik penyajian (animasi) yang kompleks

Torso adalah alat peraga yang didesain sebagai pengganti tubuh atau jasad manusia tanpa lengan dan kaki dan lebih menonjolkan penampakkan organ-organ dalam seperti jantung, paru-paru, hati, lambung, usus halus, usus besar, ginjal dan penampakan berbagai organel lain yang mendukung gambaran lengkap dari fungsi dan proses-proses yang terjadi mendukung gambaran lengkap dari segi pandang Model Torso mempunyai tiga permukaan yaitu panjang, lebar dan tinggi. Menurut Sudjana dan Rivai (2007: 163) media torso diartikan pula sebagai : Model susun (build-up model) yaitu model susunan dari beberapa objek yang lengkap, atau sedikitnya suatu bagian yang penting dari objek itu. Torso memiliki keunggulan :

1) sebagai alat bantu visual $3 \mathrm{D}$ yang dapat langsung diamati oleh siswa.

2) Torso sangat mudah digunakan, guru dan siswa dapat mendeskripsikan dengan jelas nama dan bentuk organ-organ tubuh manusia.

3) Letak organ-organ tubuh manusia dapat dipisah-pisah atau di lepas untuk keperluan peragaan di dalam kelas.

1) Metode dan Desain Penelitian
Metode yang digunakan dalam penelitian ini adalah eksperimen semu (quasi eksperimen research). Disain penelitian yang dilakukan adalah The One Shot Case Study. Pada penelitian ini peneliti hanya mengadakan treatment satu kali yang diperkirakan sudah mempunyai pengaruh, kemudian dilakukan post tes.

2) Teknik Pengumpulan Data

Teknik pengumpulan data yang digunakan dalam penelitian ini adalah teknik tes. Tes digunakan untuk mengetahui hasil belajar siswa pada sub konsep sistem pencernaan pada manusia yang diajar dengan menggunakan media pembelajaran Power Point dan media Torso.

\section{HASIL DAN PEMBAHASAN}

Dari hasil penelitian yang dilakukan, di kelompok kelas yang menggunakan media Power Point dan kelompok kelas yang menggunakan media Torso didapat rata-rata nilai kelompok kelas yang menggunakan media pembelajaran Power Point lebih tinggi dibandingkan dengan penggunaan media torso Diagram histogram dan poligon frekuensi nilai yang diperoleh kelompok siswa yang menggunakan media pembelajaran power point lebih merata dibandingkan dengan nilai yang diperoleh kelompok siswa yang menggunakan media pembelajaran torso.

Statistik hasil belajar siswa yang belajar dengan media pembelajaran power point dan torso. 


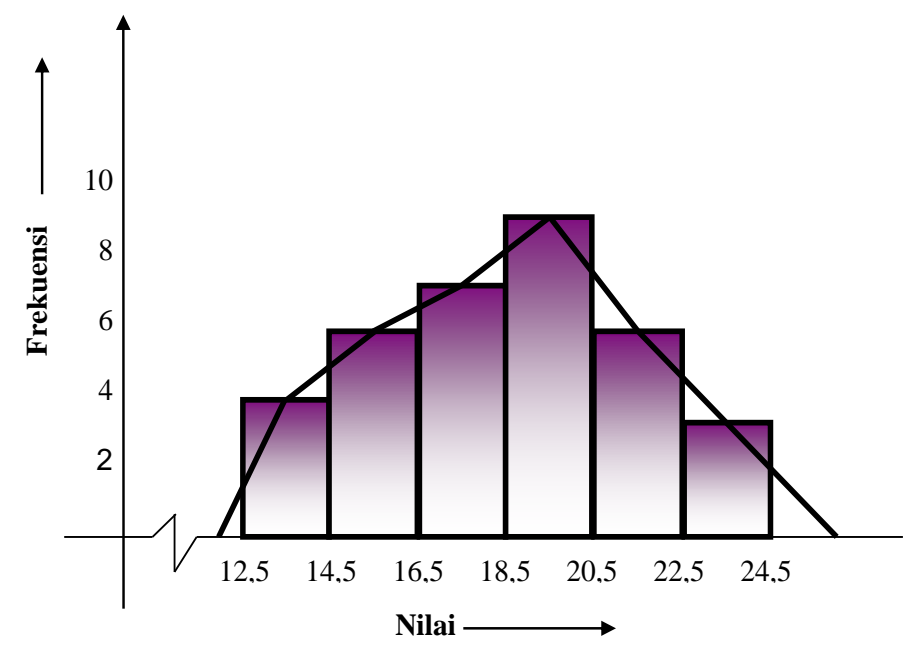

Gambar 1

Diagram Histogram dan Poligon Frekuensi Hasil Belajar Siswa yang Belajar dengan menggunakan media pemebelajaran Power Point

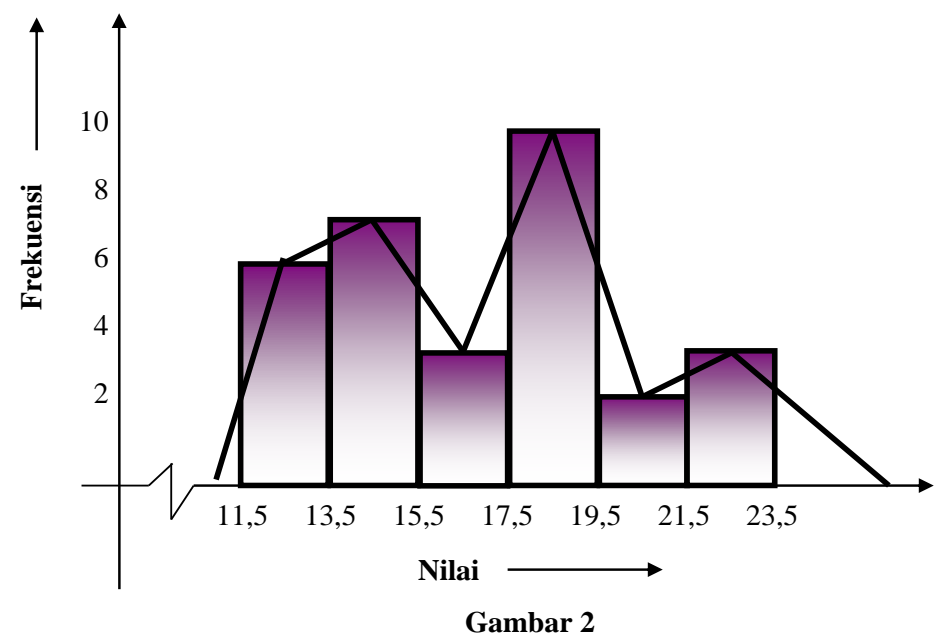

Diagram Histogram dan Poligon Frekuensi Hasil Belajar Siswa yang Belajar dengan Menggunakan Media pembelajaran Torso

Berdasarkan hasil pengujian persyaratan analisis bahwa data hasil tes belajar siswa kedua kelompok berasal dari popolasi yang berdistribusi normal dan kedua data mempunyai varians yang homogen, maka pengujian dilanjutkan dengan menggunakan uji t.

Hipotesis statistik yang akan diuji adalah :
Ho : $\mu_{\mathrm{A}}=\mu_{\mathrm{B}}:$ Tidak terdapat perbedaan rata-rata antara kedua kelompok data.

H1 : $\mu_{\mathrm{A}} \neq \mu_{\mathrm{B}}:$ Terdapat perbedaan rata-rata antara kedua kelompok data.

Kaidah pengujian hipotesis yang digunakan adalah: terima Ho jika $-\mathrm{t}$ tabel $<\mathrm{t}$ hitung $<$ $+\mathrm{t}$ table 
Tabel 4.7

\section{Ringkasan Hasil Uji t}

\begin{tabular}{|c|c|c|c|}
\hline thitung & ttabel & Hasil Analisis & Kesimpulan Analisis \\
\hline$-2,21$ & 1,99 & $\begin{array}{r}t_{\text {hitung }} \text { berada di luar interval } \\
-t_{\text {hitung }}<t_{\text {tabel }}<+t_{\text {hitung }}\end{array}$ & Tolak Ho \\
\hline
\end{tabular}

Keterangan : Perhitungan lengkap dapat dilihat pada lampiran

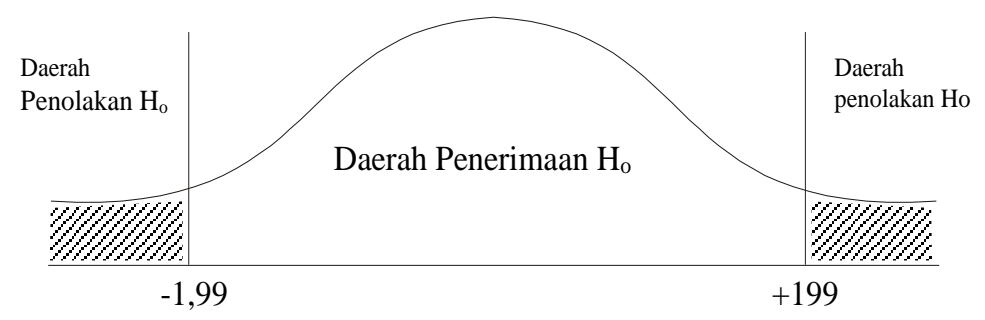

Dengan demikian, hipotesis yang penulis ajukan yaitu, terdapat perbedaan hasil belajar siswa kelas XI IA SMAN 5 Tasikmalaya semester kedua yang menggunakan media pemebelajaran powerpoint dengan media Torso bisa diterima.

Hasil belajar dengan media Torso nilai rataratanya 16,2 lebih rendah daripada hasil belajar yang menggunakan media powerpoint dengan nilai rata-rata 18,4 . Sehingga media pemebelajaran power point memiliki hasil belajar yang lebih baik

\section{SIMPULAN, REKOMENDASI \\ SARAN,}

DAN

1) Simpulan

Berdasarkan hasil analisis data dan pengujian hipotesis, maka diperoleh kesimpulan bahwa terdapat perbedaan hasil belajar siswa yang menggunakan media pemebelajaran powerpoint dengan media Torso pada Materi Pencernaan pada Manusia di kelas XI IA SMAN 5 Tasikmalaya. Kelompok kelas siswa yang menggunakan media pembelajaran powerpoint menunjukan rata-rata hasil belajar yang lebih baik dibandingkan dengan kelompok siswa yang menggunakan media pemebelajaran Torso
2) Saran dan Rekomendasi

Pada penelitian ini penulis mencoba menggabungkan penerapan model pembelajaran dengan media pembelajaran yakni, media powerpoint dengan media Torso, untuk peneliti selanjutnya penulis menyarankan untuk mencoba penggunaan media pembelajaran yang lain.

\section{DAFTAR PUSTAKA}

Anderson, L.W., dan David R.K. 2017. Kerangka Landasan Untuk Pembelajaran Pengajaran dan Asesmen. Yogyakarta: pustaka Belajar.

Aqib, Zainal .2013. Model-Model, Media, dan Strategi Pembelajran Kontekstual (Inovatif). Bandung : Yrama Widya.

Arikunto, Suharsimi. 2013. Prosedur Penelitian Suatu Pendekatan Praktik. Jakarta : Rineka Cipta.

Arsyad, Azhar. 2007. Media Pembelajaran. Jakarta : Rajagrafindo Persada.

Slameto. 2010. Belajar dan Faktor-Faktor yang Mempengaruhinya. Jakarta: Rineka Cipta

Thobroni. 2015. Belajar dan Pembelajaran Teori dan Praktik. Yogyakarta : Ar-Ruzz Media 